DOI https://doi.org/10.30525/978-9934-26-179-4-43

\title{
ШЛЯХИ ВДОСКОНАЛЕННЯ КРИМІНАЛЬНО-ПРАВОВОЇ НОРМИ УКРАЇНИ ПРО ВІДПОВІДАЛЬНІСТЬ ЗА ПОРУШЕННЯ ПРАВИЛ ПОВОДЖЕННЯ 3 БІОЛОГІЧНИМИ АГЕНТАМИ ЧИ ТОКСИНАМИ (СТ. 326 КК УКРАЇНИ)
}

\author{
Шамсутдінов О. В. \\ кандидат юридичних наук, \\ професор кафедри кримінального права, \\ кримінального процесу та криміналістики \\ Національна академія Служби безпеки Украӥни \\ м. Київ, Украӥна \\ Салагор I. М. \\ здобувач \\ Національна академія Служби безпеки України \\ м. Київ, Украӥна
}

Другий рік поспіль світлове співтовариство відчуває на собі наслідки реалізації однісї з біозагроз, про які фахівці в галузі медичної біології попереджали багато років тому. Йдеться про спалах у КНР коронавірусної хвороби, який за лічені місяці набув планетарного масштабу. За цих обставин для України, як і для будь-якої іншої держави, першочергового значення набуває питання побудови ефективної загальнодержавної системи забезпечення біобезпеки, протидії проявам біотероризму та біодиверсії, захисту населення від неконтрольованого розповсюдження патогенів, у тому числі генетично модифікованих, збереження генофонду нації, здорового та безпечного природного середовища. Важливою складовою цієї системи $\epsilon$ національне законодавство у сфері забезпечення біологічної безпеки, яке потребує вдосконалення. У цьому контексті вбачається за доцільне визначити конкретні шляхи вдосконалення вітчизняних кримінальноправових норм про відповідальність за вчинення суспільно небезпечних діянь у сфері біобезпеки.

Поряд із численними складами кримінальних правопорушень, які опосередковано стосуються сфери біологічної безпеки (передбачені, наприклад, статтями 113, 142, 239, 241-243, 251, 258, 439-442 Кримінального кодексу України, в диспозиціях яких відсутня пряма вказівка на такий предмет, засіб або знаряддя вчинення кримінального правопорушення, як небезпечні біологічні речовини, патогени, 
хвороботворні мікроорганізми, особливо небезпечні віруси, бактерії тощо), КК України містить склад злочину «порушення правил поводження з мікробіологічними або іншими біологічними агентами чи токсинами» (ст. 326), який напряму загрожує такому об'єкту кримінально-правової охорони, як біологічна безпека України. Підкреслимо, що поява в КК України (2001) вказаної кримінальноправової норми стала виконанням Україною взятих на себе зобов'язань у зв'язку із підписанням і ратифікацією Конвенції про заборону розробки, виробництва та нагромадження запасів бактеріологічної (біологічної) і токсинної зброї та про їх знищення 1972 року [1].

Здійснений нами юридичний аналіз елементів та ознак складу злочину, передбаченого ст. 326 КК України, дає підстави стверджувати, що розміщення зазначеної кримінально-правової норми серед «наркотичних» злочинів є більш ніж дискусійним, а іiі диспозиція потребує суттєвого вдосконалення. Так, родовий об'єкт злочину, передбаченого ст. 326 КК України, виходить за межі суспільних відносин у сфері забезпечення здоров'я населення і включає в себе також суспільні відносини у сфері забезпечення безпеки довкілля, зокрема об'єктів рослинного i тваринного світу, а також інших представників біоти [2, с. 264]. Зважаючи на викладене, пропонуємо доповнити Особливу частину КК України розділом «Кримінальні правопорушення проти біологічної безпеки Украӥни», до якого включити як досліджуваний злочин (ст. 326 КК) i деякі інші кримінальні правопорушення, наприклад, передбачені статтями 247 «Порушення законодавства про захист рослин», 251 «Порушення ветеринарних правил», 325 «Порушення санітарних правил і норм щодо запобігання інфекційним захворюванням та масовим отруєнням» та 441 «Екоцид» КК України, так і діяння, які на сьогодні не криміналізовані, однак посягають на генетичну цілісність людини та інших представників біоти, на природний еволюційний розвиток усіх живих організмів, тощо. Зокрема, йдеться про незаконне порушення иілісності геному особи шляхом введення в ії організм трансгенних біологічних агентів; незаконне масове порушення цілісності геному людей шляхом поширення загальнонебезпечним способом трансгенних біологічних агентів; незаконне клонування людини; ввезення на територію України та вивезення з території України клонованих ембріонів людини; незаконне виготовлення пристрою, що розсіює, розпилює чи іншим способом поширює біологічні патогенні агенти і може спричинити смерть або шкоду здоров'ю населенню чи іншим представникам біоти України, тощо. 
Повертаючись до диспозиції ст. 326 КК України, зупинимось на предметі цього злочину. Законодавцем він визначений як «мікробіологічні або інші біологічні агенти чи токсини». Однак термін «мікробіологічні агенти» в решті законодавчих та підзаконних актів України не використовується. Крім того, до змісту поняття «біологічні агенти» всі нормативно-правові акти України, які містять його визначення, включають у тому числі й «токсини». Зважаючи на це т враховуючи мету встановлення кримінально-правової заборони порушення правил поводження 3 такими агентами, пропонуємо в диспозиції ст. 326 КК України замінити визначення предмета злочину «мікробіологічні або інші біологічні агенти чи токсини» на «біологічні патогенні агенти».

На думку авторів, вдосконалення потребує також формулювання суспільно небезпечних наслідків об'єктивної сторони як простого, так і кваліфікованого складів досліджуваного злочину. Вбачається за доцільне роз'єднати делікт створення небезпеки і матеріальний склад злочину, визначивши другий окремо як кваліфікований склад (ч. 2) і передбачивши за вчинення таких діянь більш суворе покарання. Відповідно чинна частина 2 ст. 326 КК України, яка встановлює відповідальність за діяння, що потягли за собою загибель людей чи інші тяжкі наслідки, перетвориться на частину 3 і передбачатиме особливо кваліфікований склад злочину. Пропонується також уточнити зміст біологічної загрози, яка $€$ обов'язковою ознакою об'єктивної сторони простого складу досліджуваного злочину, зокрема деталізувати іiі таким чином: «небезпека для життя, здоров'я людей чи об'єктів тваринного, рослинного світу або настання інших тяжких наслідків».

Інший альтернативний обов'язковий суспільно небезпечний наслідок об'єктивної сторони складу злочину, передбаченого ст. 326 КК України,«заподіяння шкоди здоров'ю потерпілого», який запропоновано нами розглядати як конструктивну ознаку кваліфікованого складу, також потребує уточнення з огляду на неоднозначність тлумачення змісту цього поняття. Зокрема, пропонуємо використати підходи, застосовані вітчизняним законодавцем при формулюванні кваліфікованого складу порушення правил безпеки руху або експлуатації залізничного, водного чи повітряного транспорту (ч. 2 ст. 276 КК України). Тобто оперувати не оціночним поняттям, а цілком конкретними видами фізичної шкоди: «спричинення потерпілому середньої тяжкості чи тяжких тілесних ушкоджень».

Відповідно формулювання суспільно небезпечних наслідків складу злочину, передбаченого ч. 2 ст. 326 КК України, які ми пропонуємо вважати обов'язковою ознакою об'єктивної сторони особливо 
кваліфікованого складу (ч. 3 ст. 326 КК), також необхідно конкретизувати. Зважаючи на визначений нами зміст біологічної загрози, характерної для основного складу досліджуваного злочину, зазначені наслідки можна сформулювати так: «спричинення загибелі людей, їх масового захворювання, масової загибелі об'єктів тваринного чи рослинного світу, або інших тяжких наслідків».

Наступним напрямком вдосконалення чинної кримінально-правової норми про відповідальність за порушення правил поводження 3 біологічними патогенними агентами (ст. 326 К України) вбачається визначення в диспозиції окремих ознак суб'єктивної сторони досліджуваного складу злочину як кваліфікуючих. Зокрема, доцільним $\epsilon$ запозичення підходу німецького законодавця, який у відповідній кримінально-правовій нормі (п. 4 ч. $1 \S 330$ КК ФРН) передбачив як кваліфікуючу ознаку, яка обтяжує покарання, корисливий мотив при порушенні встановленого порядку поводження 3 біологічними патогенними агентами [3]. У цьому контексті пропонуємо доповнити диспозицію нової ч. 2 ст. 326 КК України такою альтернативною конструктивною ознакою суб'єктивної сторони кваліфікованого складу порушення правил поводження з біологічними патогенними агентами, як мотив, зокрема сформулювати цю позицію таким чином: «або вчинене з корисливих мотивів».

Завершуючи висловлення пропозицій щодо вдосконалення диспозиції досліджуваної кримінально-правової норми, звернемо увагу на суб'єкта цього злочину. Зокрема, на сьогодні існують різні погляди на те, загальний чи спеціальний суб'єкт є характерним для складу злочину, передбаченого ст. 326 КК України. Аби зняти вказані дискусії, керуючись бланкетним характером диспозиції відповідної норми та особливостями iï санкції (зокрема, додатковим покаранням) автори пропонують в диспозиції ч. 1 ст. 326 КК вказати на ознаки спеціального суб'єкта. Найбільш прийнятним вбачається підхід, застосований вітчизняним законотворцем при формулюванні ознак спеціального суб'єкта порушення правил безпеки під час виконання робіт 3 підвищеною небезпекою (ст. 272 КК України): «особа, яка зобов'язана їх (правил) дотримувати».

\section{Література:}

1. Конвенция о запрещении разработки, производства и накопления запасов бактериологического (биологического) и токсинного оружия и об их уничтожении от 10 апреля 1972 года. URL: http://zakon.rada. gov.ua/laws/show/995_054 (дата звернення: 26.11.2021). 
2. Матвійчук В.К. Теоретичні та прикладні проблеми кримінальноправової охорони навколишнього природного середовища: монографія. Київ: Національна академія управління, 2011. 368 с.

3. Strafgesetzbuch : in der Fassung der Bekanntmachung vom 13. November 1998 (BGBI. I S. 3322), das zuletzt durch Artikel 47 des Gesetzes vom 21. Dezember 2020 (BGBI. I S. 3096) geandert worden ist. URL: https://www.gesetze-im-internet.de/stgb/BJNR001270871.html (дата звернення: 26.11.2021).

\title{
DOI https://doi.org/10.30525/978-9934-26-179-4-44
}

\section{КРИМІНАЛЬНА ВІДПОВІДАЛЬНІСТЬ ЗА СТІЙКІ ЗЛОЧИННІ ОБ'ЄДНАННЯ}

\author{
Шульженко Н. В. \\ кандидат юридичних наук, дочент, \\ асистент кафедри кримінального права \\ Національний юридичний університет імені Ярослава Мудрого; \\ старший науковий співробітник \\ Науково-дослідний інститут вивчення проблем злочинності імені \\ академіка В. В. Сташиса \\ Національної академії правових наук України \\ м. Харків, Україна
}

Діяльність стійких злочинних об'єднань перешкоджає розвитку нашої держави у напрямку євроінтеграції. Відповідно до п. 1 постанови Пленуму Верховного Суду України «Про практику розгляду судами кримінальних справ про злочини, вчинені стійкими злочинними об’єднаннями» від 23. 12. 2005 р. № 13 вказано, що при розгляді кримінальних справ про злочини, вчинені стійкими злочинними об'єднаннями, необхідно враховувати: норми Кримінального кодексу України, в яких визначено особливості кримінальної відповідальності осіб, котрі вчинили злочини у співучасті (статті 26-31); ознаки злочину, що вказують на його вчинення організованою групою (ч. 3 ст. 28) або злочинною організацією (ч. 4 ст. 28); положення статей Особливої частини КК, якими передбачено додаткові ознаки спеціальних видів таких груп чи організацій (статті 257, 258, 260) [1]. 